\title{
Brand Personality's Influence on the Purchase Intention: A Mobile Marketing Case
}

\author{
Olfa Bouhlel \\ Member of the Research Unit MaPReCoB \\ Higher Institute of Management, University of Sousse, Tunisia \\ 79 Rue Tahar Sfar, 4070, M'saken, Sousse, Tunisia
}

Tel: 216-2229-1370Ｅ-mail: olfabouhle12002@yahoo.fr

Nabil Mzoughi (Corresponding author)

Member of the Research Unit MaPReCoB

Higher Institute of Management, University of Sousse, Tunisia

BP 37, Khézama-Est, 4051, Sousse, Tunisie

Tel: 216-2326-2416 E-mail: teachershello@yahoo.fr

\author{
Dorsaf Hadiji \\ Member of the Research Unit MaPReCoB
}

Higher Institute of Management, University of Sousse, Tunisia

Tel: 216-2251-8222Ｅ-mail: dorsafhadiji@yahoo.com

\author{
Ichrak Ben Slimane \\ Member of the Research Unit MaPReCoB \\ Higher Institute of Management, University of Sousse, Tunisia \\ 7 Avenue Ali Ibn Abi Taleb, 2074, Tunis, Tunisia \\ Tel: 216-9733-7018Ｅ-mail: ichrakbs@yahoo.fr
}

Received: December 2, 2010 Accepted: January 11, $2011 \quad$ doi:10.5539/ijbm.v6n9p210

\begin{abstract}
This study underlines the value of the brand personality and its influence on consumer's decision making, through relational variables. An empirical study, in which 380 participants have received an SMS ad, confirms that brand personality does actually influence brand trust, brand attachment and brand commitment. The levels of brand sensitivity and involvement have also an impact on the brand personality and on its related variables.

Keywords: Mobile marketing, Brand personality, Involvement, Sensitivity, Trust, Attachment, Commitment, Purchase intention

\section{Introduction}

Branding and brand-based differentiation are important means for creating and sustaining competitive advantage (Aggarwal, 2004). Many useful constructs and measurements have been developed recently in the branding literature including brand personality, brand community, brand trust and brand attachment (Carroll and Ahuvia, 2006; Thomson, McInnis and Park 2005; Delgado-Ballester, Munuera-Alemán and Yagüe-Guillén, 2003; McAlexander, Schouten and Koenig, 2002; Aaker, 1997). Those researches suggested that people could form relationships with brands in much the same way in which they form relationships with each other in a social context. Freling and Forbes (2005) suggest that brand personality could differentiate and create competitive advantage in the consumer's minds for brands that otherwise are indistinguishable from their competitors. The brand personality is "an inanimate object associated with personality's lines resulting from interactions that the
\end{abstract}


consumer has with it or through the marketing communication" (Plummer, 1984). A well established brand personality influences consumer preference and patronage (Malhotra and Naresh, 1988 ; Sirgy, 1982) and develops stronger emotional ties (Biel, 1993), trust, and attachment with the brand (Fournier, 1998. Contrarily to product attributes which are mainly functional, brand personality tends to have a "symbolic function and one of self-expression" (Keller, 1993). With the notion of one-to-one marketing, marketers are shifting away from mass marketing (Barwise and Farley, 2005). Nowadays, the target should be approached in a personalized, interactive and immediate way. Customers should be addressed individually, one at time (Peppers, Rogers and Dorf, 1999).

Advances in information and communication technologies are nowadays offering new marketing channels to companies. Their influence conducts their businesses and shapes their marketing strategies (Barutcu). The use of wireless mobile communication technology is on the rise. This technology system allows the "anytime-to-anyplace" communication. The mobile marketing offers opportunities to reach consumers. It facilitates interactivity and personalization of the content and the message context (Heinonen and Strandvik, 2003).

This paper aims to define the individuals profile who, under the influence of the brand personality, are the most susceptible to maintain a strong relationship with it and to buy the product after a short message service ad (advertising). It presents the results of a case study research concerning mobile marketing campaigns and values the relational approach of the brand personality and the mobile marketing on the purchase intention.

Among the large variety of mobile devices that can be used for mobile advertising activities, the investigation focuses on push marketing activities in form of text advertising messages sent to Tunisian consumers. This research focuses on the communication by SMS, the relationship between brand personality and mobile marketing as well as the influence of the mobile marketing on the purchase intention.

The managerial interest is to study the mini message, as a daily mean of communication, adapted to the management of brand equity.

\section{Theoretical background and hypotheses}

Brand and consumer relationships have been the latest research focus in brand research. Blackston (1992) compared brand relationships to interpersonal relationships and established a new research direction by pointing out that "intimate, permanent, stable relationship can form the interaction between a brand and its consumers". Studies have noted that consumers differ not only in how they perceive brands but also in how they relate to them (Muniz and O'Guinn, 2001; Fournier, 1998). Some consumers become so attached to brands that they develop emotional relationship with them.

That brands have personalities or human characteristics is now well established in the literature, as is the idea that brand personality is a vehicle of consumer self-expression and can be instrumental in helping a consumer express different aspects of his or her self (Johar, Sengupta and Aaker, 2005; Escalas, and Bettman, 2005; Rohm and Swaminathan, 2004; Belk, 1988; Aaker, 1997). The brand personality provides the brand with a "soul' that is essential to construct brand image. It refers to the emotional side of a brand image (Ouwersloot and Tudorica, 2001), to a psychological and human characteristic whereas brand image is about the attributes related with the brand (Aaker, 1997).

\subsection{From the human personality to the brand personality}

Brand personality traits are formed and influenced by any direct or indirect contact that the consumer has with a brand. The trait approach states that personality is a set of traits, defined as "any distinguishable, relatively enduring way in which one individual differs from others" (Batra, Lehmann and Singh, 1993). It is a "tendency to show coherent modes of cognition, affect and behavior" (Costa and McCrae, 1998). It is about psychological phenomena giving sense to the action and to the human experience. Personality can be defined as "the consistency of interaction towards a person's external and internal stimuli" (Fiske, 1971).

Consumers exploit brands to construct and to maintain their identity (Fiske, 1982) and to experience emotional gratification (Aaker, 1996; O'Donohoe, 1993). Fournier (1998); Fournier and Yao (1997) persuasively demonstrate the existence of a consumer-brand relationship by highlighting the ways in which brands can be animated, humanized, or to some extent personalized.

The dimensions of brand personality are defined by extending the dimensions of human personality to the domain of brands. The brand can be extrovert, friendly, conscientious, old-fashioned, modern, exotic, etc. (Pantin-Sohier, 2004). The "Big Five" model of personality structure is built around five factors: extraversion, conscientiousness, agreeableness, openness and neuroticism (Digman, 1997; Goldberg, 1990; McCrae and Costa, 1987; 1983). It corresponds to the dominant modeling theory of the lines (Funder, 2001; John, 1990). Aaker (1997) developed a brand personality scale on the basis of personality scales from psychology, personality scales used by marketers, and the original qualitative research of a numbers of brands' personality traits. A large number of variables have been mentioned in the literature as influencing brand personality: brand name, brand symbol or logo, celebrity endorser, color, shape, country of origin, price, music, packaging, sales promotions, etc. (Mc Cracken, 1989; Ogilvy, 1985; Aaker, 1997; Plummer, 1984; Keller, 1993; Fiske, 1971; Pantin Sohier, 2004). 
The brand personality differentiates the brand from its competitors (Pantin Sohier, 2004), contributes to brand equity (Aaker, 1999; Biel, 1993) and is able to enhance trust in the brand, brand attachment and the formation of consumer-brand relationships (Fournier, 1998). The brand personality measures include elements of trust (Davies, Chun, da Silva and Roper, 2001; Phau and Lau, 2001) and they appear to have a strong influence on customer brand attachment. Brand personality lines help consumers express their self-concept and experiment symbolic benefits from the possession or consumption of brands (Ouwersloot and Tudorica, 2001; Johar, Sengupta and Aaker, 2005). Marketers attempt to differentiate and build preference for their brands not only on the basis of how consumers perceive them functionally but also on the basis of these brand personality perceptions (Keller, 1993; Aaker, 1997).

\subsection{Consumer-brand relationships}

Several researches works have further examined the roles of trust, commitment, and attachment in the relationship that customers have built with the brand (Sirieix and Dubois, 1999; Anderson and Narus, 1990).Theoretical contributors argue that consumer's trust in brands is an essential ingredient for the success of the relationship (Anderson and Weitz, 1992; Crosby, Evans and Cowles, 1990; Moorman, Zaltman and Desphandé, 1992; Berry, 1995; Fournier, Dabscha and Mick, 1998). Brand trust is whereby one part in a relationship. Commitment is also recognized to be central to the relationship enhancement (Morgan et Hunt, 1994; Fournier, Dobscha and Mick, 1998; McAlexander, Schouten and Koenig, 2002; Anderson and Narus, 1990). Hess (1995) linked trust and commitment, calling them 'key variables' in the exchange network between a company and its various partners. Trust can lead to the commitment to a relationship which results from an exchange partner exerting all his effort to preserve an important relationship (Chaudhuri and Holbrook, 2001).

Schlenker, Helm and Tedeschi (1973) suggested that in some consumption environments, consumers form strong attachments to brands that might predict their commitment, and their willingness to make sacrifices in order to maintain the relationship. Consumer-brand relationships also help the individual to maintain the self-identity. Consumers will engage in relationships with brands that have similar personalities to their own (Hess, 1995).

\subsubsection{Brand trust}

Trust is conceptualized as "a belief, in keeping with the tenets of social psychology research, or as willingness or behavioral intention" (Hess, 1995). It is the consumer's brand perceptions: altruism, honesty and potential performance of the product (Hess, 1995).

In marketing literature, brand trust is defined as the "willingness of the average consumer to rely on the ability of the brand to perform its stated function" (Chaudhuri and Holbrook, 2001). Costa and McCrae (1998) states that brand trust is a willingness to rely on an exchange partner in whom one has confidence. To rely, it is to count on information received from another person about uncertain states of the environment and their consequences on a situation of risk (Hiscock, 2001). The trust is a central value of the partner relation (Bowen and Shoemaker, 1998; Fournier, Dobscha and Mick, 1998) it acts to reduce perceived risk and to increase confidence in the consumer-brand relationship. It results from the expertise, the reliability and the intentionality (Pavlou, 2003).

The ultimate goal of marketing is to generate an intense bond between the consumer and the brand, and the main ingredient of this bond is trust (McKnight, Choudhury and Kacmar, 2002). It has been empirically tested as a key factor in the initiation and maintenance of any long-term relationship. Trust leads to customer loyalty and commitment (Yoon, 2002; Hess, 1995; Anderson and Narus, 1990). The trust can be endowed with a predictive value of the future behavior (Anderson and Narus, 1990). Its role on the explanation of the purchase intention is enhanced in various researches (Yoon, 2002; Andreassen and Lindestad, 1997; Gurviez and Korchia, 2002; Delgado-Ballester and Munuera-Aleman, 2001).The brand trust literature takes the stand that consumers trust brands that are good and honorable, and hold positive brand images and personalities (Ferrandi and Valette-Florence, 2002; Hiscock, 2001). The consumer trusts on a brand when he perceives it as credible, honorable and friendly (Gurviez, 1999). Cristau (2006) consider brand trust as a feeling of security that is held by the consumer that the brand will meet their consumption expectations .

The brand personality is a means of differentiation within a product category and an important factor affecting preference (Biel, 1993). It arouses feelings and raises the level of trust and fidelity (Lacoeuilhe, 1999). Researchers proposed that brand personality boosts consumer preference and usage (Sirgy, 1982), induces emotions in consumers (Biel, 1993), and has a positive relationship with levels of trust and loyalty (Fournier, 1998). The trust on the relationship consumer - brand is "a psychological variable or more a state of faith or assumption that the brand, as a personified entity, makes a commitment to have a predictable action and conform to his expectations, and to maintain with benevolence this orientation in the duration " (Lacoeuilhe, 2000).

\section{H1: Brand personality influences positively the brand trust.}

\subsubsection{Brand Attachment}

The attachment is "a durable emotional and psychological relation with the brand which results from the concomitance of friendship feelings and from brand dependence" (Lacoeuilhe, 1997). It "translates a durable and inalienable emotional reaction to the brand and expresses a psychological relation" (Temessek and Touzani, 2004; 
Michel and Vergne, 2004). It is the "psychological variable which explains a global indecomposable vision along attributes, taking the shape of a holistic vision and which expresses an emotional psychological nearness" (Cristau, 2001); Heilbrunn, 2001). A consumer is attached to a brand because of precise meaning profits (Heilbrunn, 2001). It is independent from the context of purchase (Onkvisit and Shaw, 1987) and from the brand instrumental value (Sheth and Parvatiyar, 1995).

Consumers will engage in relationships with brands that have similar personalities to their own. They can transpose the attachment towards the persons into the brands (Belaid and Lacoeuilhe, 2005; Ganesan, 1994; Beatty, Homer and Kahle, 1998; Thomson, McInnis and Park, 2005). According to the congruence theory, the consumer becomes attached to the brand among which the personality, the values and the image are in adequacy with his self concept and with the image that he made of himself or that he wants to transmit to the others (Geyer, Doston and King, 1991).

Based on the premise that brands can have personalities in much the same way humans have. Brand personality is seen as a valuable factor in increasing engagement and brand attachment, in a similar way to how people relate to and bond with other people.

\section{H2: Brand personality has a positive impact on the brand attachment.}

The attachment is a state of psychological link between the customer and the firm. It forms on the long term and constitutes one of the results of a successful relation (Lastovicka and Gardner, 1979). The trust loosens on the long term this nearness and the identification with the partner, within a relational exchange framework (Hess, 1995). Brand attachment allows predicting certain number of behavior: trust, commitment and brand loyalty (Taylor, 1981).

\section{H3: Brand trust has a positive impact on the attachment.}

\subsubsection{Brand commitment}

By strengthening their relationships with committed customers, firms can prevent them from being poached by competitors. Commitment arises from Human resources (Terrasse, 2003). Fournier, Dobscha and Mick (1998) extended this concept into the world of products and brands; they define it as an enduring desire to maintain a valued relationship. It is a long-term orientation, including the desire to maintain a relation (Bettencourt, 1997). The commitment towards the brand is "an implicit or explicit intention to maintain a durable relation with a brand" (Michel and Vergne, 2004). It is an "emotional or psychological attachment to a brand inside a given product category" (Zeithaml, Berry and Parasuraman, 1996; Aaker, 1991; Beauvois and Joule, 1989). Brand commitment reflects the degree to which a brand is firmly entrenched as the only acceptable choice within its product class (Frisou, 1996).

It is the will to prolong a satisfying relation to the long term and this by facing the short-term sacrifices (Moulins, 2003; Samuelsen and Sandvik, 1998; Geyskens, Steenkamp, Scheer and Kumar, 1996; Allen and Meyer, 1993; Fournier, 1998). The notion of exclusive fidelity is used to define the commitment (Geyskens, Steenkamp, Scheer and Kumar, 1996). The fidelity to the partner (Allen and Meyer, 1990) strengthens by a process of auto-intensification (Amine, 1999 in Fullerton, 2003). The commitment can result from various motivations (Gilliland and Bello, 2002; Hrebiniak, 1974; Walsh, 2005; Amine, 1994). It possesses a double nature: emotional and rational (Onkvisit and Shaw, 1987; Beatty, Homer and Kahle, 1988). It is emotional, of hedonist essence (Amine, 1998), when it corresponds to a desire to belong to the firm and to adopt its values and its objectives (McQueen J. and al., 1993; Debenedetti, 2004). It is calculative, instrumental or rational, of cognitive essence (Walsh, 2005), when the customer adopts a behavior based on an economic decision, rational and arbitrated by the change costs.

Commitment has its roots in identification, shared values, attachment, and trust (Schlosser and Shavitt, 1999; Dussart, 1983; Hess, 1995). Hiscock (2001) have found a positive relationship between trust and commitment for consumer products. Trust would be the cardinal forerunner of consumer commitment, once the consumer has established trust in a brand he is willing to engage in a long-term relationship with it. Relationships characterized by trust are so highly valued that consumers will desire to commit themselves to such relationships (Hosmer, 1995).

\section{H4: Brand trust has a positive influence on consumer's brand commitment.}

Commitment plays a critical role in determining resistance to various actions such as brand transgressions and outside attacks to the brand (Moorman, Zaltman and Desphandé, 1992; Geyskens and Steenkamp, 1995). Change resistance raises the ambiguity between the attachment and the commitment (Amraoui, 2004; Flavian and Guinaliu, 2006; Geyskens, Steenkamp, Scheer and Kumar, 1996). It underlines the link which can exist between them. Commitment is a psychological attachment to a brand.

Consumers' emotional attachments to a brand might predict their commitment to the brand and their willingness to make financial sacrifices in order to obtain it (Thomson, McInnis and Park, 2005). The attachment constitutes a factor of emotional brand commitment (Onkvisit and Shaw, 1987; Zainuddin, Russell-Bennett and Charmine, 2007; De Reuyter, Wetzels and Birgelen, 1998; Fullerton, 2003). It establishes change barrier and proves the 
consumer's loyalty (Allen and Meyer, 1993). We protect and we defend the object, we refuse to abandon it and we develop feelings toward it (Cristau, 2001; Onkvisit and Shaw, 1987). It has no direct impact on the repetitive purchase behavior, but indirect through the commitment (Fournier, 1997).

\section{H5: There is a positive relation between brand attachment and brand commitment.}

\subsection{Consumer relationships and purchase intention}

Constructs of purchase intention and consumer attitudes, and their effect on consumer behavior have been the focus of considerable direct marketing research (Debling, 1998). The purchase intention is the probability of purchase of a product or a given brand (Lacoeuilhe, 1997). It is "an expressed attitude concerning a future choice behavior and of economic decisions" (Marketing Dictionary). The reciprocal and mutual benefits of consumer-brand relationship provide a solid foundation for the further development of a long-term relationship between consumer and firm. Satisfied customers, who foresee the reduced uncertainty and opportunity cost of staying with the same firm, are more likely to repurchase from that firm. Hiscock (2001) showed that both brand trust and brand commitment has a positive impact on future purchase intention, either directly or indirectly, through consumer relationship willingness. Trusting and committed customers are more likely to repurchase from the same firm (Hiscock, 2001; Hess, 1995). Consequently, relationship marketing practices can help firms to achieve relationship marketing success in terms of repeat purchases of customers by capitalizing on the consumer relationship that is embedded in the existing customers who have trust in and commitment to the brand.

Trust towards a brand reassures the consumer. It allows simplifying his process of choice and reducing the necessary time for the decision-making (Crosby and Taylor, 1983). It also contributes to subjugate the purchase uncertainty (Bhattacharya, Rao and Glynn, 1995). It generates a globally positive attitude (Morgan et Hunt, 1994), which influences positively the brand evaluation. The more the reliable level granted to the brand by the customer is important, the more his purchase intention is high (Bhattacharya, 1998; Lacoeuilhe, 1999). Kapferer and Laurent (1983), reveals that the development of trust not only affects the intention to buy, also directly affects the effective purchasing behavior.

\section{H6: There is a positive relation between consumer's brand trust level and purchase intention.}

At a higher level of commitment, consumers reveal preference toward a brand, and reflect this preference in brand purchase. The buyer is likely to engage in repeat purchase of that product or brand because he or she has associated good feelings with being a customer of that brand and has their personal identity reinforced (Szymaroski and Bush, 1987). The commitment influences positively the intention to durably maintain a relationship, the desire to invest (Kapferer and Laurent, 1989) and the acceptance of short-term sacrifices (Kapferer and Laurent, 1992; D'Astous and Gargouri, 2001). It establishes a predictor of the repetitive brand purchase. It is the immediate precursor of the behavioral activity (Allen and Meyer, 1993). The commitment reflects the consumer's desire to maintain a durable relationship with brand (Fournier, 1998; D'Astous and Gargouri, 2001). It results from previous purchases and appears during customer's prosper or difficult periods, and even on momentary brand difficulties (Allen and Meyer, 1993). The will to pursue this relation is implicitly evoked. The commitment possesses two main behavioral consequences: the intention of buy back in order to maintain the relation [Moulins, 2003; Debenedetti, 2004) and change resistance (Gharbi, Ben Achour and Ayari, 2004; McEnally and De Chernatory, 1999).

\section{H7: Brand commitment has a positive effect on purchase intention.}

Other key focal areas of research in the relational bonding literature discuss a consumer's involvement and identification within the service consumption process (Dobni and Zinkhan, 1990; Semprini, 1999). Consumers have a relationship with many brands in everyday life. The brand sensitivity varies according to the consumer's belief of differentiation (Ratier, 2003; Kapferer and Thoenig, 1994), the perception of his choice competence and to his involvement towards the product (Gouteron, 2006; Michon and Changeur, 2003). The perceived competence, or the feeling of knowing how to choose, is also a determiner of the sensitivity (Ratier, 2003).

\subsection{Moderators: brand sensitivity, involvement towards the brand}

\subsubsection{Brand sensitivity}

A consumer is sensitive when he tries to identify the product brand, if he considers it in his decision process (Kapferer and Thoenig, 1992). A person sensitive to a brand is interested on the identity and on the values conveyed by this one. Being sensitive to a brand is to attach a big importance for brand names during the choice and during the purchase (Rothshild, 1984), but this sensitivity is not limited to the purchase decision-making (Houston and Rothschild, 1978; Sohierr, 2004). It refers also to the consumer's attachment to a brand or to a set of brands. The interest for the brand name outstrips the one granted to the information concerning the price, the functional characteristics of the product and the joined services (Müller and Chandon, 2002). The sensitivity reflects the relative weight of the brand name compared to the other features of the product on the preference formation. It is often likened to loyalty (Ganesan, 1994). It is a psychological, not directly observable variable measuring the importance of the brand in the decision process. 
The brand sensitivity represents the nature and the relation intensity between the consumer and the brand (Ganesan, 1994). This relation can be cognitive, emotional or symbolic.

The relation is cognitive when it results from the information treatment process underlying the sensitivity. The differentiation between brands depends on their attributes. When the consumer is novice, incapable or not motivated to handle the product information, his brand sensitivity will increases. The brand name becomes a criterion of essential choice. But if he is a connoisseur, his sensitivity will lie on the brands differentiation and on their capacity to satisfy his needs. Brands that have high perceived value will be included in the purchaser's choice. As such, brand personality is considered important as it might help differentiating brands (Laurent and Kapferer, 1985) and as it might enable researchers to better understand and interpret the brand image concept (Strazzieri, 1994). The differentiation between brands leads to an emotional attachment to one or to a group of brands. In a purchase situation, the attitude is dominant and reduces the customer's decision-making to a recall of the brand. In this case, the sensitivity is equivalent to the brand attachment (Olshavsky and Granbois, 1979). The relation is symbolic when the sensitivity is based on the imagination and when it translates a link between the brand's system of meanings and the consumer's values (Fournier, 1998).

The brand is a symbolic resource in the construction of the consumer's identity (Lacoeuilhe, 1999). Considered as a personified authority (Ben Miled, 2001; Aaker, 1997; Muniz and O'Guinn, 2001), it gives a sense to the product consumption (Johar, Sengupta and Aaker, 2005; Davies, Chun; da Silva and Roper, 2001).

For a product category, the sensitivity level differs within consumers (Dawar and Pillutla, 2000; Michon and Changeur, 2003). The same customer can be sensitive to a product category and not to another (Kapferer and Laurent, 1992; D'Astous and Gargouri, 2001). The brand sensitivity constitutes a stake in the connections between producers and distributors (Kapferer and Thoenig, 1992; Olshavsky and Granboi, 1979). The more it is strong, the less the distributor has the possibility of developing his clientele loyalty.

The more an individual perceives a purchase risk, the more he grants interest to the brand (Kapferer and Thoenig, 1992). The more the consumer is involved on the purchase, the more he estimates to give a certain image of himself, and the more he counts on the brand to help him. This influence is stronger when the consumer is involved on the products category or when his sensitivity to the brand is strong. The object's symbolic or expressive connotation makes the customer more susceptible to the personality (Haghirian and Madlberger, 2005; Kapferer and Thoenig, 1992). If the consumer is not sensitive to the brand, he can modify his behavior according to a given circumstance and decide to cancel or to postpone the purchase, or even more he will choose another brand. When the consumer is sensitive to brand, its seriousness will arouse his trust (Michon and Changeur, 2003). If the sensitivity has a strong intensity and if the involvement on the product category is high, the brand personality will facilitates the trust.

\section{H8: the more sensitive the consumer to brand the more positive brand personality effects on the trust.}

The attachment is a psychological variable underlying individual brand sensitivity (Michona nd Changeur, 2003). A brand sensitive consumer is committed in a cognitive and emotional way (Zainuddin ,Russell-Bennett and Hartel, 2007). His choice varies according to the brand nature and importance on the purchase process (Bourke, 2006). The congruence perception between the self concept and the brand personality may explain the brand attachment.

\section{H9: the more sensitive the consumer to the brand the more positive the effect of the brand personality on the attachment.}

\subsubsection{Involvement towards the brand}

It is a non observable motivation, excitement or interest created by an object or a specific context (Krishnamurthy, Sandeep, 2003) which consequences are the research and the information's treatment as well as the decision-making (Scharl, Dickinger and Murphy, 2004). It is considered as an individual variable.

It is a feature, a state or a process (Vargo and Lusch, 2004). A feature is a durable individual characteristic. The state is temporary and allows describing the intensity, the direction and the nature of the consumer's interest. The involvement can also be a process, which is translated by behavioral answers going from the research information to the purchase decision (Bourke, 2006). It results from external and internal stimuli. The involvement is conceptualized from the familiarity, the attachment to the product and from the congruence between this one and the individual's values (Samuelsen and Sandvik, 1998 in Vargo and Lusch, 2004). It is multidimensional and includes five factors: interest, pleasure, value of sign, importance of the risk and probability to make a mistake during the choice (Tsang, Ho and Liang, 2004).

Clickatell (2004) in an attempt to develop a comprehensive definition of involvement recognize three types of involvement; the enduring involvement, the situational involvement and response involvement. The first type refers to the strength of the pre-existing relationship between the individual and the product it is elicited by intrinsic interest on the product. Enduring involvement reflects relatively stable state that is subject to change over a long period of time (Scharl, Dickinger, and Murphy, 2004). It reflects its cognitive and emotional structures as well as his past behavior (Clickatell, 2004). The enduring involvement predicts regular behavior in 
the brand personal relation such as the levels of information processing and the advertising sensitivity (Bauer, Barnes, Reichardt and Newmann, 2005). The involvement is situational, contextual, temporary or passing when it is induced by concerns about the consequences of one's behavior (Krishnamurthy and Sandeep, 2003).

Response involvement can therefore be viewed as the outcome of enduring involvement and the situational involvement. It translates the complexity and the cognitive and behavioral processes area characterizing the decision process. A high response involvement generates extensive and complex activities of data collection and processing (Bauer, Barnes, Reichardt and Newmann, 2005; Karjaluoto, Leppäniemi and Salo, 2004).

\section{H10: The more involved the consumer on the product category the more positive the impact of the brand} personality on the trust.

The more the consumer is involved in the products category, the more important his purchase. His expertise being besides stronger, his reaction will be probably less influenced by emotional factors such as the brand attachment (Aaker, Benet-Martinez and Garolera, 2001).

\section{H11: The more involved the customer in the product category the more negative the effect of the brand personality on the attachment.}

\subsection{Mobile Marketing enhances Consumer-brand relationship}

Brands need to build a new relationship with their consumers by reinforcing their presence and participation in networks and communities. They need to communicate with a new approach their value and the contract they propose.

Mobile marketing emphasizes the building of long-term relationships. It allows reciprocal communication processes between marketer and consumers. Marketing activities supported by mobile devices allow companies to directly communicate with their consumers without time or location barriers (Aaker, Fournier and Brasel, 2004).

The interaction between consumers and their mobile phones, together with the ability afforded by mobile advertising to control the viewing environment provides advertisers with an opportunity to build more meaningful brand relationships than at any time in advertising history (Ahluwalia, Unnava, and Burnfrant, 2001). Mobile communication has become part of our daily lifestyle.

There are different synonyms for mobile-advertising, such as wireless advertising (Ho and Kwok, 2003) or wireless advertising messaging. Advertising via mobile devices or mobile Marketing is defined "as the usage of interactive wireless media (such as cellular phones and pagers, cordless telephones, personal digital assistants, two-way radios, baby crib monitors, wireless networking systems, GPS-based locators and maps) to transmit advertising messages to consumers in form of time and location sensitive, personalized information with the overall goal to promote goods and services" (Ahluwalia, Unnava and Burnfrant, 2001).

The Mobile Marketing Association (MMA, 2003) defines mobile marketing as "any form of marketing, advertising or sales promotion activity aimed at consumers".

Yuan and Cheng (2004) define mobile marketing as using a wireless medium to provide consumers with timeand location-sensitive, personalized information that promotes products, services and ideas.

The Mobile advertising accelerates relationship marketing by providing better interactivity and connectivity it helps serving customers (Turchetti, 2003).

As an extension of the Internet environment, the high penetration of mobile phones in recent years has created a good opportunity for wireless Internet applications, including wireless marketing and advertising (Turchetti, 2003). Nowadays, the mobile marketing adoption and acceptance is so on the rise. Mobile phones have already become a marketing tool for retailers and manufacturers. The main reasons underlying the high expectations laid to mobile channel refers to its high reach, low cost and high retention rates (Barutcu, 2008).

Personalized messages increase participants' motivation to attend to marketing-related information and induce favorable attitudes toward the ad and advertiser. Heinonen and Strandvik (2003) concluded that marketing communication in mobile channels are challenging because of the personal nature of a mobile phone.

Mobile advertising relaxes the mobility constraint associated with fixed-line Internet access; it offers direct communication with consumers, anytime and anyplace (Turchetti, 2003). Mobile phones are usually carried everywhere and kept within reach of their owners. They are ideal for use in conjunction with a variety of traditional media tools such as indoor and outdoor advertising and broadcast channels (Yuan and Cheng, 2004). The mobile phone is a highly interactive medium that enables the recipient of a message to reply to it immediately. When consumers use their mobile devices to enroll in a service that provides them with advertising of their choice, they voluntarily give information about themselves and the messages they want to receive (Peppers, Rogers and Dorf, 1999). The "opt - in" services has the ability to quickly inform the subscribers of the availability of a promotion or of an innovative service. It is an effective medium to generate traffic by motivating a determined target to contact a call center or to visit a point to sell. The Shorts Message Service (SMS) is a massive and a powerful support of communication with strong relational power. It is an immediate, automated, 
reliable, personal, discreet and customized channel (Karjaluoto, Leppäniemi, and Salo, 2004; Yuan and Cheng, 2004).

\section{Model and research hypotheses}

This section discusses the conceptual model of the study and indicates the resulting hypothesis. The personality affects the type and the strength of the relation consumer/ brands (Barutcu, 2008). It is an antecedent of the relational variables: trust, attachment and commitment. It has a capacity relation through the trust, the attachment and the commitment of the client (Barwise and Farley, 2005).

The following model (figure 2) presents the process leading to the purchase intention after receiving an SMS ad. Two other concepts are integrated as moderators: brand sensitivity and brand involvement.

\section{Methodology}

\subsection{Sampling and data collection procedure}

The investigation was conducted in Sousse located in the East-Center of Tunisia (North Africa). A non-probability sampling method by using a convenience sampling was adopted. The study requires that the survey respondents should have received commercials SMS from "prêt-à-porter" brands. According to the objectives of this study and research variables, as well as different dimensions in the conceptual structure, the questionnaire survey was developed. Before the questionnaire was conducted, it was pre-tested using a judgment sample of 28 mobile phone users, and was subsequently revised to improve readability and understanding. During the period of the survey from 12/04/2010 until 17/06/2010 a total of 380 subjects (36.2 percent male, 63.8 percent female) participated in the experiment. In terms of the respondent's education, $9 \%$ of the respondents have high school degree, $0.6 \%$ have primary school degree and $90.4 \%$ have undergraduate degree. $65 \%$ of the respondents have monthly salary between 200-500 Tunisian Dinars and 35\% between 500-1500 Tunisian Dinars (Table1).

\subsection{Measures}

The seven aforementioned constructs: brand personality, brand sensitivity, Brand involvement, Brand trust, Brand attachment, Brand commitment and Purchase intention are each measured on five-point Likert scales ranging from 1 (strongly disagree) to 7 (strongly agree). A review of the literature provided the input for identifying the items included in the self-administered survey instrument used. The scales used in the research are shown recapitulating in table 2 .

\section{Results}

The data was entered into SPSS 17.0 and checked for incorrect entries and missing data. A series of exploratory factor analyses (EFA) were first performed in order to purify the scales and to examine their dimensionality. Internal consistency of measurements was then assessed using Cronbach's alpha. The dependent and independent variables being metric, simple and multiple regressions were applied, in order to validate the research hypotheses. The moderating effect of the brand sensitivity and the involvement on the relation between the brand personality and the dependent variables trust and attachment was also verified by regressions.

\subsection{Psychometrics properties of the scales}

This section evaluates the measurement scales used in the research. The validity and internal consistency of the measurement scale were estimated. To evaluate the measurement scales,

(1) Each measurement was subjected to principal component factor (PCA) analysis. The Kaiser-Meyer-Olkin (KMO) measure of sampling adequacy and Bartlett's Test of Sphericity (BTS) were applied to the data prior to factor extraction to ensure that the characteristics of the data set were suitable for exploratory factor analysis. The results indicated that our data satisfied the psychometric criteria for factor analysis to be performed.

The analysis extracted six expected factors: brand personality, brand trust, brand commitment, brand sensitivity, brand involvement and future purchase intention, with each item being loaded onto its corresponding factor. As outlined in Table 3, PCA results show that trust, attachment, commitment, brand sensitivity and involvement are one-dimensional.

(2) Cronbach's alpha was applied also: this statistic is considered an adequate index of the inter-item consistency of independent and dependent variables as supplied by the SPSS program. The Cronbach alphas came to 0.794, $0.833,0.784,0.777,0.794,0.875$, for brand personality, brand trust, brand attachment, brand commitment, brand sensitivity and brand involvement constructs respectively.

\subsection{Test of the mediating variables}

The relationship brand/consumer is associated with only two dimensions of the brand personality: sincerity and competence. The hypothesis $\mathrm{H} 1$ which aimed to test whether brand trust is positively influenced by the brand personality is confirmed. The test $t$ is significant for both extracted dimensions (Table 4).

When the customer judges the brand sincere, he estimates on a rational and cognitive way and believes consciously and durably on its integrity (Ben Miled Cherif, 2001). The sincerity and the competence are, for a 
'prêt à porter" brand, personalities lines which develop a reliable feeling for the individuals having received an advertising SMS. A brand perceived as sincere develops, in time, relations more stable and more intense than the existing brands (Krishnamurthy and Sandeep, 2003). Brands that are seen as 'sincere' will earn relationship advantages similar to friendship development between humans, thus increasing relationship strength (Yuan and Cheng, 2004). Results are presents in table 5.

As presented in table 5 the postulated positive influence of the sincerity $(B=0.197 ; \mathrm{T}=4.164 ; \mathrm{p}=0.000)$ and of the competence $(\beta=0.102 ; \mathrm{T}=2.191 ; \mathrm{p}=0.029)$ on the attachment was also significant. The hypothesis $\mathrm{H} 2$ is thus approved. The more the brand personality is positively perceived, is considered sincere and competent, the more attached the customer to the brand.

Additionally, the trust's influence on the attachment tested in H3 was confirmed ( $(=0.464 ; \mathrm{T}=9.033 ; \mathrm{p}=0.000)$ as well as the influence of the brand trust and the commitment $(B=0.396 ; \mathrm{T}=8.032 ; \mathrm{p}=0.000)$. Trust and commitment are considered to be central constructs in building long-term relationships with customers. There is a positive relationship between trust and commitment (H4 confirmed).

The positive effect of the attachment on the brand commitment $(\beta=0.350 ; \mathrm{T}=7.107 ; \mathrm{p}=0.000)$ was also verified in this empirical analysis. These results show that the trust and the attachment are the main antecedents of the commitment. Trust is a determinant of relationship quality (Dussart, 1983).

The regression confirms the hypothesis $\mathrm{H} 5$ according to which the brand trust affects positively the purchase intention $(\beta=0.225 ; \mathrm{T}=3.955 ; \mathrm{p}=0.000)$. The test $\mathrm{t}$ is significant for $\mathrm{H} 7(\beta=0.356 ; \mathrm{T}=6.256 ; \mathrm{p}=0.000)$. The commitment thus possesses an impact on the purchase intention. This relationship is translated by a positive brand attitude (Hess, 1995; Fournier, 1998) and preference, the will to continue using it or even the resistance to competition. It also influences the efficiency of the communication. The committed customers are less permeable to other brands commercials (Dussart, 1983). The commitment is preliminary determiner of the decision-process.

\subsection{Moderating effect of the sensitivity and the involvement of the relationship between brand personality and} brand trust

The sensitivity and the involvement have a positive moderating effect on the relations between the brand personality and the trust, (H8 and H9), and on the brand personality and the attachment, on the other hand (H10 and H11).

The hypothesis $\mathrm{H} 8$ and $\mathrm{H} 9$ were partially confirmed $(\mathrm{R} 2=0.193 ; \mathrm{F}=84.369 ; \mathrm{p}=0.000 ; \mathrm{R} 2=0.081 ; \mathrm{F}=30.830$; $\mathrm{p}=0.000$ ). The sensitivity and the involvement do not influence the relationship between the sincerity and the trust. The moderations (sensitivity: $0.439 ; \mathrm{T}=9.185 ; \mathrm{p}=0.000$ and involvement: $0.284 ; \mathrm{T}=5.552 ; \mathrm{p}=0.000$ ) concern only the impact of the competence on the trust (table 6).

H10 was also partially confirmed. The effect is positive, with one partial moderation on behalf of the sensitivity ( $\mathrm{R} 2=0.134 ; \mathrm{F}=54.730 ; \mathrm{p}=0.000)$. The values relative to $\mathrm{H} 11$ are also significant $(\mathrm{R} 2=0.163 ; \mathrm{F}=68.525 ; \mathrm{p}=0.000)$. This result concerns only moderation affecting the competence. The sensitivity plays a determining role in the psychological process which precedes the purchase [131].

The more the consumer perceives the advertising SMS as a useful means, the more attached the consumer to the brand. To strengthen the level of trust and attachment to a given brand, it's better to emphasize on its sincerity and competence, by using the mobile marketing. Trust, sincerity and competence are translated by a feeling of brand attachment [140]. The latter is strong when individuals are involved and sensitive to brands [140]. The similarity between brand personality and the customer helps companies explain and predict the target behavior $[140]$ and to exploit the potential of the mobile marketing through a clear, understandable and direct strategy.

\section{Conclusion and contributions}

The growth of mobile advertising as a powerful communication tool with considerable audience reach has opened a new area for research (Amraoui, 2004). The objective of this study was to estimate the interest of the brand personality on the Tunisian's customer purchase decision through relational variables, after receiving an ad SMS within the framework of a campaign of mobile marketing. An inquiry, with 380 individuals receiving a SMS on behalf of brands of "prêt à porter "clothing, was realized.

The mobile marketing process with its associated technology enables companies to send advertisements directly to targeted customers that are personalized, and location and time specific. Mobile phones have the potential to be ideal personalized tools (Blackston, 1992) for providing an opportunity for marketers to send an offer at the right time to the right consumer (Kapferer and Laurent, 1983). It is a new direct marketing device that provides direct access to consumers and interacts with them in a very personal way. This phenomenon has lead to SMS being touted as the hottest communications medium of the century (De Reuyter, Wetzels, and Birgelen, 1998). By using this advertising technique brands built their image which in turn would enhance customer experience and satisfaction for a long term commitment.

The results of this study show that attaching personalities to brands can make them more desirable to the consumer. Brand personality influences the trust and the attachment as well as the commitment. The more the consumer perceives the brand as being sincere and competent, the more he trusts it, what generates his 
attachment and his commitment. The levels of sensitivity and involvement modify the impact of the brand personality on the consumer behavior. The consumer purchase intention increases after receiving a SMS announcing a new collection, a period of sales...

As does any research, this study has some limitations that must be evaluated. The scale of the personality of the used brand is not completely adapted to the Tunisian context. Some items were not understandable by some members. A specific tool of measure must be thus developed. In addition, the sample was drawn primarily from the university students.

The conclusions elaborated above not only deliver valuable implications for marketing practitioners but also reveal some major directions for future research on mobile marketing. It would be interesting to identify the mobile phone users, their demographic characteristics and their attitudes toward mobile shopping.

The risk perception and the permission marketing issues should be analyzed as well. In this context it will be necessary to thoroughly survey consumers' main sources of risk perception and also reveal how consumers prefer to provide permission and profile information.

\section{References}

Aaker D.A. (1991). Managing Brand Equity. New York, Free Press.

Aaker J. (1999). The malleable self: The role of self-expression in persuasion. Journal of Marketing Research, vol. 36, Feb, p. 45-57. doi:10.2307/3151914, http://dx.doi.org/10.2307/3151914

Aaker J.L. (1996). Exploring Brand Equity: Building Strong Brands. New York, The Free Press.

Aaker J.L. (1997). Dimensions of Brand Personality. Journal of Marketing Research, 34(3), 347-356. doi:10.2307/3151897, http://dx.doi.org/10.2307/3151897

Aaker J.L., Benet- Martinez V., and Garolera J. (2001). Consumption symbols as carriers of culture: A study of Japanese and Spanish brand personality constructs. Journal of personality and social psychology, 81(3), 249-264. doi:10.1037/0022-3514.81.3.492, http://dx.doi.org/10.1037/0022-3514.81.3.492

Aaker, J., Fournier, S., and Brasel, S. (2004). When Good Brands Do Bad. Journal of Consumer Research, 31(1), 1-16. doi:10.1086/383419, http://dx.doi.org/10.1086/383419

Aggarwal, P. (2004). The Effects of Brand Relationship Norms on Consumer Attitudes and Behavior. Journal of Consumer Research, 31(1). doi:10.1086/383426, http://dx.doi.org/10.1086/383426

Ahluwalia, R., Unnava, R., and Burnfrant, R. (2001). The moderating role of commitment on the spillover effect of marketing communications. Journal of Marketing Research, 38, November, 458-470. doi:10.1509/jmkr.38.4.458.18903, http://dx.doi.org/10.1509/jmkr.38.4.458.18903

Allen N., and Meyer J. (1990). The measurement and antecedents of affective continuance and normative commitment to the organization. Journal of Occupational Psychology, 63, 1-18

Allen N., and Meyer, J. (1993). Organizational commitment: evidence of career the effects. Journal of Business Research, 26, 49-61. doi:10.1016/0148-2963(93)90042-N, http://dx.doi.org/10.1016/0148-2963(93)90042-N

Amine A. (1994). Implication du Consommateur et Fidélité aux Marques. Cahier de recherche.

Amine A. (1998). Product importance, consumer knowledge and brand loyalty/ Some empirical evidence about their relationship, New Developments \& Approaches in Consumer Behavior Research. Mc Millers Press Limited, London.

Amine A. (1999). Consumer true brand loyalty, the central role of commitment. Journal of Strategic Marketing.

Amraoui L. (2004). Relation entre risque et confiance en la marque : une étude exploratoire. Actes du XXème Congrès de l'Association Française de Marketing, St Malo.

Anderson E., and Weitz B. (1992). The use of pledges to maintain and sustain commitment in distribution channels. Journal of Marketing Research, February, 18-34. doi:10.2307/3172490, http://dx.doi.org/10.2307/3172490

Anderson, J.C.-Narus, J.A. (1990). A model of distributor firm and manufacturer firm working partnerships. Journal of Marketing, 54(1), pp.42-58. doi:10.2307/1252172, http://dx.doi.org/10.2307/1252172

Andreassen, T.W., \& Lindestad, B. (1997). Customer Loyalty and Complex Services: the impact of corporate image on quality, customer satisfaction and loyalty or customers with varying degrees of service expertise. International Journal of Service Industry Management, 8(4), 01-33.

Barutcu. (2008). Consumer's Attitudes Toward Mobile Marketing and Mobile Commerce in Consumer Markets. Ege Academic Review, 8 (1) 2008: 15-32.

Barwise, P., \& Farley, J.U. (2005). The state of interactive marketing in seven countries: interactive marketing comes of age. Journal of Interactive Marketing, 19(3), 67-80. doi:10.1002/dir.20044, http://dx.doi.org/10.1002/dir.20044

Batra R., Lehmann D.R., and Singh D. (1993). The brand personality component of brand goodwill: some 
antecedents and consequences. Brand Equity and Advertising, editions Aaker and Biel, Hillsdale, NJ: Lawrence Erlbaum Associates, 83-96.

Bauer, H. H., Barnes, S. J., Reichardt, T., \& Newmann, M. M. (2005). Driving consumer acceptance of mobile marketing: A theoretical framework and empirical study. Journal of Electronic Commerce Research, 6(3), 181-192.

Beatty, S., Homer, P., and Kahle, 1998, The involvement-commitment model: theory and implications. Journal of Business Research, 16, 149-167. doi:10.1016/0148-2963(88)90039-2, http://dx.doi.org/10.1016/0148-2963(88)90039-2

Beatty, Sharon E., Pamela M. Homer, and Lynn R. Kahle. (1988). Problems with VALS in International Marketing Research: An Example From An Application of The Empirical Mirror Technique. Advances in Consumer Research, 15, 375-380.

Beauvois J.L., and Joule R.V. (1989). Une Théorie Psychosociale : la Théorie de l'Engagement. Recherche et Applications en Marketing, 4(1), 79-90.

Belaïd S., and Lacoeuilhe J. (2005). Une validation interculturelle de l'échelle d'attachement à la marque, Actes du XXIème Congrès de l'Association Française de Marketing, 18-20 Mai, NANCY.

Belk R.W. (1988). Possessions and the extended self. Journal of Consumer research, 15(2), 139-167. doi:10.1086/209154, http://dx.doi.org/10.1086/209154

Ben Miled-Cherif H. (2001). L'implication du consommateur et ses perspectives stratégiques. Recherche et Applications en Marketing, 16(1), 65-85.

Berry L.L. (1995). Relationship marketing of service-growing interest, emerging perspectives. Journal of the academy of marketing science, 23, 4, 236-245. doi:10.1177/009207039502300402, http://dx.doi.org/10.1177/009207039502300402

Bettencourt L. (1997). Customer voluntary performance: customers as partners in service delivery. Journal of Retailing, 7, 383-406. doi:10.1016/S0022-4359(97)90024-5, http://dx.doi.org/10.1016/S0022-4359(97)90024-5

Bhattacharya, C.B. (1998). When customers are members: Customer retention in paid membership contexts. Journal of the Academy of Marketing Science, 26, (1), 31- 44. doi:10.1177/0092070398261004, http://dx.doi.org/10.1177/0092070398261004

Bhattacharya, C.B., Rao, H., and M.A. Glynn. (1995). Understanding the bond of identification: An investigation of its correlates among art museum members. Journal of Marketing, 59 (4), 46-57. doi:10.2307/1252327, http://dx.doi.org/10.2307/1252327

Biel A. (1993). Converting image to equity in Brand equity and advertising. Editions Aaker D. And Biel A., Hillsdale, NJ: Lawrence Erlbaum Associates, 67-82.

Blackston M. (1992). Observations: Building Brand Equity by Managing the Brand's Relationship. Journal of Advertising Research, 32(3), 79-83.

Bourke. (2006). How to Develop a Mobile Marketing Strategy Integrating mobile into the mix to increase brand awareness, generate leads and win sales. [Online] Available: http://www.dynamiclogic.com/eu/events/docs/Aerodeon_MobileStrategy_v100,pdf.

Bowen, J., and Shoemaker, S. (1998). Loyalty: a strategic commitment. Cornell and Restaurant and Administration Quarterly, 39, 12-25. doi:10.1177/001088049803900104, http://dx.doi.org/10.1177/001088049803900104

Buchanan T. (1985). Commitment and leisure behaviour, a theoretical perspective. Leisure Science, 7, 401-420. doi:10.1080/01490408509512133, http://dx.doi.org/10.1080/01490408509512133

Carroll and Ahuvia. (2006). Some antecedents and outcomes of brand love. Marketing Letters, 17, 79-89. doi:10.1007/s11002-006-4219-2, http://dx.doi.org/10.1007/s11002-006-4219-2

Chaudhuri Arjun \& Holbrook Morris. (2001). The Chain of Effects from Brand Trust and Brand Affect to Brand Performance: The Role of Brand Loyalty. Journal of Marketing, 65(2), 81-93. doi:10.1509/jmkg.65.2.81.18255, http://dx.doi.org/10.1509/jmkg.65.2.81.18255

Christophe Terrasse. (2003). Proposition et validation d'une échelle de l'engagement à la marque, Actes du congrès international de l'Association Française de Marketing.

Clickatell, (2004). [Online] Available: http://www.clickatell.com/press/press_article.php/47

Costa Jr. P.T., and McCrae R.R. (1998). Trait theories of personality, Advanced personality, edition. Barone, Hersen and Van Hasselt, Plenum Press, New-York, 103-121.

Cristau C. (2001). Les facteurs d'Attachement / Engagement aux Marques comme Source de Capital de Marque, Thèse de Doctorat en Sciences de Gestion, Université Aix-Marseille III.

Cristau C. (2006). L'attachement à une marque : conjonction de l'indépendance et de l'amitié. Revue française 
du Marketing, 207.

Crosby L., and Taylor J. (1983). Psychological commitment and its effects on post-decision evaluation and preferences stability among voters. Journal of Consumer Research, 9, 413-431. doi:10.1086/208935, http://dx.doi.org/10.1086/208935

Crosby, L. A., Evans, K. R., \& Cowles, D. (1990). Relationship quality in services selling: an interpersonal influence perspective. Journal of Marketing, 54(3), 68-81. doi:10.2307/1251817, http://dx.doi.org/10.2307/1251817

D'Astous, A., and Gargouri E. (2001). Consumer Evaluations of Brand Imitations. European Journal of Marketing, 35(1/2), 153-167.

Davies, Gary, Rosa, Chun; Rui, V. da Silva and Stuart, Roper. (2001). The personification metaphor as a measurement approach for corporate reputation. Corporate Reputation Review, 4(2), pp. 113-127, ISSN: 1363-3589

Dawar, N. et Pillutla, M. N. (2000). Impact of Product-Harm Crises on Brand Equity: The Moderating Role of Consumer Expectations. Journal of Marketing Research, 37 (May), 215-226. doi:10.1509/jmkr.37.2.215.18729, http://dx.doi.org/10.1509/jmkr.37.2.215.18729

De Reuyter K., Wetzels M., and Birgelen M. (1998). Marketing service relationships: the role of commitment. Journal of business and industrial marketing, 13(4-5), 406 - 423.

Debenedetti A. (2004). L'Attachement au Lieu: état de l'art et perspectives de recherche dans le cadre des lieux de loisirs, IX Journées de Recherche en Marketing de Bourgogne.

Debling F. (1998). Mail myopia, examining financial services from a brand commitment Perspective. Marketing Intelligence and Planning, 16(1), 38-46. doi:10.1108/02634509810199517, http://dx.doi.org/10.1108/02634509810199517

Delgado-Ballester, E., \& Munuera-Aleman, J. L. (2001). Brand trust in the context of consumer loyalty. European Journal of Marketing, 35 (11/12), 1238-1258. doi:10.1108/EUM0000000006475, http://dx.doi.org/10.1108/EUM0000000006475

Delgado-Ballester, E., Munuera-Alemán, J.L., \& Yagüe-Guillén, M.J. (2003). Development and validation of a brand trust scale. International Journal of Market Research, 45 (1), 35-53.

Digman J.M. (1997). Higher-order factors of the big five. Journal of Personality and Social Psychology, 73(6), 1246-1256. doi:10.1037/0022-3514.73.6.1246, http://dx.doi.org/10.1037/0022-3514.73.6.1246

Dobni D., and G.M. Zinkhan. (1990). In Search of Brand Image: A Foundation Analysis. Advances in Consumer Research, 17, pp. 110-119.

Dussart C. (1983). Le comportement du consommateur et les stratégies marketing, collection de Mac Grow Hill éditeur, 14.

Escalas, Jennifer Edison and James R. Bettman. (2005). Self- Construal, Reference Groups, and Brand Meaning. Journal of Consumer Research, 32 (3), 378-389. doi:10.1086/497549, http://dx.doi.org/10.1086/497549

Ferrandi J.M., and Valette-Florence P. (2002). Premier test et validation de la transposition d'une échelle de personnalité humaine aux marques. Recherche et Application en Marketing, 17(3), 21-40.

Fiske, D. W. (1971). Measuring the concepts of personality. Chicago, Aldine.

Fiske, S.T. (1982). Schema triggered affect: Applications to social perception, in Affect and Cognition: The 17th Annual Carnegie Symposium on Cognition, Margaret S.Clark and Susan T. Fiske, eds. Hillsdale, NJ: Lawarence Erlbaum Associates

Flavian C and Guinaliu M. (2006). Consumer Trust, Perceived Security and Privacy Policy: Three Basic Elements of Loyalty to a Web Site, industrial Management and Data Systems, 106 (5), 601-620.

Fournier S. (1997). Brands: Love, Hate and in between. Harvard Business review, March-Apr, 8-9.

Fournier S. (1998). Consumers and their brands: developing relationship theory in consumer research. Journal of Consumer Research, 24, 343-373. doi:10.1086/209515, http://dx.doi.org/10.1086/209515

Fournier S., Susan Dobscha and David G. Mick. (1998). Preventing the premature death of relationship marketing. Harvard Business Review, 76 (1), 42-51.

Fournier, S., \& Yao, J.L. (1997). Reviving brand loyalty: A reconceptualization within the framework of consumer-brand relationships. International Journal of Research in Marketing, 14, 451-472. doi:10.1016/S0167-8116(97)00021-9, http://dx.doi.org/10.1016/S0167-8116(97)00021-9

Freling T. H., and Forbes L. P. (2005). An empirical analysis of the brand personality effect. Journal of Product and Brand Management, 14 (7), pp 404-413. doi:10.1108/10610420510633350, http://dx.doi.org/10.1108/10610420510633350

Frisou J. (1996). Les Théories Marketing de la Fidélité : Un Essai de Validation Empirique sur le Marché des 
Services de Télécommunication, Mémoire de DEA, Université des Sciences et Techniques de Lille, Septembre. Fullerton G. (2003). When Does Commitment Lead to Loyalty? Journal of Services Research, 5(4), 33-344. doi:10.1177/1094670503005004005, http://dx.doi.org/10.1177/1094670503005004005

Funder D.C. (2001). Personality. Annual Review of Psychology, 52, 197-221. doi:10.1146/annurev.psych.52.1.197, http://dx.doi.org/10.1146/annurev.psych.52.1.197

Gaëlle P-S and DECROP A. The influence of the product's color an shape on brand personality, Actes de colloques, 12th International Product Development Management Conference, Copenhagen, Danemark.

Ganesan S. (1994). Determinants of long term orientation in buyer-seller relationships. Journal of Marketing Research, 58, April, 1-19.

Garbarino E., \& Johnson M.S. (1999). The different roles of satisfaction, trust, and commitment in customer relationships. Journal of Marketing, 63, 4, 70 - 87. doi:10.2307/1251946, http://dx.doi.org/10.2307/1251946

Geyer P., Dotson M. et King R. (1991). Predicting brand commitment. Mid Atlantic Journal of Business, June, 129-138.

Geyskens I ., Steenkamp J.B., Scheer L., and Kumar N. (1996). The effect of trust and interdependance on relationship commitment: A trans-atlantic study. International Journal of Research in Marketing, 13, 22-27. doi:10.1016/S0167-8116(96)00006-7, http://dx.doi.org/10.1016/S0167-8116(96)00006-7

Geyskens I., and Steenkamp J.B. (1995). An investigation into the joint effects of trust and interdependence on relationship commitment. Actes de la Conference de l'EMAC, 24, Ed. M. Bergadaa, ESSEC, Cergy - Pontoise, $351-371$.

Gharbi J.E., Ben Achour A.A., and Ayari M. (2004). Relation entre les traits de l'individu, l'émotion et la confiance dans le site.

Gilliland, D.I., and D.C. Bello. (2002). Two Sides to Attitudinal Commitment: The Effect of Calculative and Loyalty Commitment on Enforcement Mechanisms in Distribution Channels. Journal of the Academy of Marketing Science, 30(1), 24-43. doi:10.1177/03079450094306, http://dx.doi.org/10.1177/03079450094306

Goldberg L.R. (1990). An alternative description of personality: the Big- Five factor structure. Journal of personality and Social Psychology, 59 (6), 1216- 1229. doi:10.1037/0022-3514.59.6.1216, http://dx.doi.org/10.1037/0022-3514.59.6.1216

Gouteron J. (2006). L'impact de la personnalité de la marque sur la relation marque-consommateur, application au marché du prêt-à-porter féminin. Revue Française du Marketing, 207, Avril, 43-59.

Gurviez P. (1999). La confiance comme variable explicative du comportement du consommateur : Proposition et validation d'un modèle de la relation de la marque intégrant la confiance, Actes du Congrès International de l'Association Française de Marketing, 15 éds J.-C. Usunier et P. Hetzel, Université Louis Pasteur Strasbourg, 301-326.

Gurviez P., and Korchia M. (2002). Proposition d'une échelle de mesure multidimensionnelle de la confiance dans la marque. Recherche et Application en Marketing, 17(3), 41-61.

Haghirian, P., and Madlberger, M. (2005). Consumer attitude toward advertising via mobile devices - An empirical investigation among Austrian users. In the Proceedings of the 13th European Conference on Information Systems, Regensburg, Germany.

Heilbrunn B. (2001). Les facteurs d'attachement du consommateur à la marque, Thèse de Doctorat en Sciences de Gestion, Université Paris IX Dauphine.

Heinonen K., and Strandvik T. (2003). Consumer Responsiveness to Mobile Marketing. [Online] Available: http://web.hhs.se/cic/roundtable2003/papers/D22Heinonen_Strandvik.pdf

Hess J. (1995). Construction and assessment of a scale to measure consumer Trust, Conference AMA Educators' Enhancing Knowledge development in Marketing, Editions B.B. Stern et G.M. Zinkhan, 6, 20-25.

Hiscock, Jennifer. (2001). Most Trusted Brands. Marketing, March 1st, 32-33.

Ho, S.Y., and Kwok, S.H. (2003). The Attraction of Personalized Service for Users in Mobile Commerce: An Empirical Study. ACM SIGecom Exchanges, 3(4), 10-18. doi:10.1145/844351.844354, http://dx.doi.org/10.1145/844351.844354

Hosmer, L. T. (1995). Trust: The connecting link between organizational theory and philosophical ethics. Academy of Management Review, 20, 379-403.

Houston M.J., and Rothschild M.L. (1978). Conceptual and methodological perspectives in involvement, in Research Frontiers in Marketing: Dialogues and Directions, S. JAIN (ed.), Chicago, American Marketing Association, 184-187.

Hrebiniak, L. G. (1974). Effects of Job Level and Participation or Employee Attitudes and Perceptions of Influence. Academy of Management Journal, 17, 649-662. doi:10.2307/255644, 
http://dx.doi.org/10.2307/255644

Johar, G. V., J. Sengupta, and J. L Aaker. (2005). Two roads to updating brand personality impressions: Trait versus evaluative inferences. Journal of Marketing Research, 42(4), pp.458-469. doi:10.1509/jmkr.2005.42.4.458, http://dx.doi.org/10.1509/jmkr.2005.42.4.458

John O.P. (1990). The big five factor taxonomy: Dimensions of personality in the natural language and in questionnaires, Handbook of Personality: theory and research, editions Pervin, New York: Guilford Press, 66-100.

Kapferer J.N and Thoenig J.C. (1994). Les consommateurs face à la copie: étude sur la confusion des marques créée par l'imitation. Revue Française du Marketing, 136, 53-66.

Kapferer J.N. ,and Thoenig J.C. (1992). La marquee. McGraw Hill, Paris.

Kapferer J.N., and Laurent G. (1992). La sensibilité aux marques, Paris, éditions d'Organisation.

Kapferer J-N and G. Laurent. (1989). La sensibilité à la marque, dans Kapferer J-N. et J-C. Toenig (Eds), La marque, McGraw Hill, Paris, 93-124.

Kapferer J-N and Laurent G. (1983). La Sensibilité aux Marques. Fondation Jours de France pour la Recherche en Publicité, Paris.

Karjaluoto, H. Leppäniemi, M., \& Salo, J. (2004). The role of mobile marketing in companies' promotion mix: empirical evidence from Finland. Journal of International Business and Economics, 2(1), 111-116

Keller K.L. (1993). Conceptualizing, measuring and managing customer-based brand equity. Journal of Marketing, 57(1), 1-22. doi:10.2307/1252054, http://dx.doi.org/10.2307/1252054

Krishnamurthy, Sandeep. (2003). E-Commerce Management. South-Western, Mason, OH. 76-84.

Lacoeuilhe J. (1997). Le rôle du concept d'attachement dans la formation du comportement de fidélité. Revue Française du Marketing, 165(5), 29-42.

Lacoeuilhe J. (1999). Proposition d'une échelle de mesure de l'attachement à la marque. Actes du Congrès International de l'AFM, Strasbourg, 1-13.

Lacœuilhe J. (2000). L'attachement à la marque : proposition d'une échelle de mesure. Recherche et Applications en Marketing, 15 (4), 61-77.

Lastovicka J.L., and Gardner D.M. (1979). Components of involvement. Attitude research plays for high stakes, J.C. Maloney et B. Silverman (eds), Chicago, American Marketing Association.

Laurent G., and Kapferer J-N. (1985). Measuring Consumer Involvement Profiles. Journal of Marketing Research, 22, 1, 41-53. doi:10.2307/3151549, http://dx.doi.org/10.2307/3151549

Malhotra, Naresh K. (1988). Self Concept and Product Choice: An Integrated Perspective. Journal of Economic Psychology, $\quad 9$ (March), 1-28. http://dx.doi.org/10.1016/0167-4870(88)90029-3

Mc Cracken G. (1989). Who is the celebrity endorser? Cultural foundations of the endorsement process, Journal of Consumer Research, 16(3), 310-321. doi:10.1086/209217, http://dx.doi.org/10.1086/209217

McAlexander, James H., John W. Schouten and Harold J. Koenig. (2002). Building Brand Community. Journal of Marketing, Vol. $66 \quad$ (January), 38-54. doi:10.1509/jmkg.66.1.38.18451, http://dx.doi.org/10.1509/jmkg.66.1.38.18451

McCrae R.R., and Costa Jr P.T. (1983). Social desirability scales: more substance than style. Journal of Consulting and Clinical Psychology, 51(6), 882-888. doi:10.1037/0022-006X.51.6.882, http://dx.doi.org/10.1037/0022-006X.51.6.882

McCrae R.R., and Costa Jr P.T. (1987). Validation of the five factor model of personality across instruments and observers. Journal of Personality and Social Psychology, 52, 81-90. doi:10.1037/0022-3514.52.1.81, http://dx.doi.org/10.1037/0022-3514.52.1.81

McEnally M., and De Chernatory L. (1999). The evolving nature of branding: Consumer and managerial considerations. Journal of Consumer and Market Research, 99(2), 1999.

McKnight, D. H., Choudhury, V., \& Kacmar, C. (2002). Developing and validating trust measures for e-commerce: An integrative typology. Information Systems Research, 13(3), 334-359. doi:10.1287/isre.13.3.334.81, http://dx.doi.org/10.1287/isre.13.3.334.81

McQueen J., and al. (1993). Decomposing a Brand's Consumer Franchise into Buyer Types, in Brand Equity and Advertising, ed, D.A. Aaker et A. Biel, Hillsdale, NJ, Lawrence Erlbaum.

Michel G. et Vergne J.F. (2004). Comment expliquer l'attachement aux e-marques : applications aux Sites de Ventes en Ligne ?, Actes du XXème Congrès de l'Association Française de Marketing, 6 et 7 Mai, Saint Malo.

Michon C., and Changeur S. (2003). Une étude des réactions du consommateur face aux crises sur les marques. Congrès International : les tendances du marketing, Venise. 
Moorman C., Zaltman G., \& R. Desphandé. (1992). Relationships between Providers and Users of Market Research: the Dynamics of Trust within and between Organizations. Journal of Marketing Research, 29, 31 4-328.

Morgan R.M., and Hunt S.D. (1994). The commitment-trust theory of relationship marketing. Journal of Marketing, 58, 3, 20-38. doi:10.2307/1252308m, http://dx.doi.org/10.2307/1252308

Moulins J.L. (2003). Risque perçu et fidélités à la marque. Actes du Congrès International de l'Association Française de Marketing.

Müller B., and Chandon J.L. (2002). L'impact de la visite du site Internet sur la personnalité de la marque, Actes du Congrès de l'Association Française de Marketing, 18, Lille, 81-98.

Muniz, Albert, M., and Thomas O'Guinn. (2001). Brand Community. Journal of Consumer Research, 27 (March), 412-32. doi:10.1086/319618, http://dx.doi.org/10.1086/319618

O'Donohoe, S. (1993). Advertising Uses and Gratifications. European Journal of Marketing, 28(8/9): 52-75. doi:10.1108/03090569410145706, http://dx.doi.org/10.1108/03090569410145706

Ogilvy D. (1985). Ogilvy on advertising. Random House, New York.

Olshavsky, R.W., \& Granbois, D.H. (1979). Consumer decision making - Fact or fiction. Journal of Consumer Research, 6, septembre, 93-100. doi:10.1086/208753, http://dx.doi.org/10.1086/208753

Onkvisit and Shaw. (1987). Self-concept and image congruence. Journal of Consumer Marketing, Winter, 13-23

Ouwersloot, H., \& Tudorica, A. (2001). Brand personality creation through advertising. Maxx Working Paper Series, University of Maastricht.

Pavlou, P. A. (2003). Consumer Acceptance of Electronic Commerce-Integrating Trust and Risk with the Technology Acceptance Model. International Journal of Electronic Commerce, 73, 69-103.

Peppers, D, Rogers, M \& Dorf, B. (1999). Is Your Company Ready For One-To-One Marketing? Harvard Business Review, Jan-Feb.

Phau I. et Lau K.C. (2001). Brand personality and consumer self-expression: single or dual carriageway? Brand management, 8, 6, 428-444.

Plummer J. T. (1984). How personality makes a difference. Journal of Advertising Research, 24, 27-31.

Ratier M. (2003). L'image de marque à la frontière de nombreux concepts, Juillet, Cahier de recherche no. 2003 - 158, Centre de Recherche en Gestion, Toulouse.

Rohm, A., \& Swaminathan, V. (2004). A Typology of Online Shoppers Based on Shopping Motivations. Journal of Business Research, 57(7), 748-757. doi:10.1016/S0148-2963(02)00351-X, http://dx.doi.org/10.1016/S0148-2963(02)00351-X

Rothshild M.L. (1984). Perspectives on involvement: current problems and future directions, Advances in Consumer Research, T.C. Kinnear ed., Ann Arbor, MI: Association for Consumer Research, 11, 216-217.

Samuelsen B., and Sandvik K. (1998). Effects of customer state of commitment to service providers, in Proceedings of the 27th EMAC Conference, 1, 345-350.

Scharl, A., Dickinger, A., \& Murphy, J. (2004). Diffusion and success factors of mobile marketing. Electronic Commerce Research and Applications, 4. 159-173. doi:10.1016/j.elerap.2004.10.006, http://dx.doi.org/10.1016/j.elerap.2004.10.006

Schlenker, B.R., Helm, R, \& Tedeschi, J.T. (1973). The effects of personality and situational variables on behavioral trust. Journal of Personality and Social Psychology, 25, 419-427. doi:10.1037/h0034088, http://dx.doi.org/10.1037/h0034088

Schlosser, A., \& Shavitt, S. (1999). Effects of an approaching group discussion on product responses. Journal of Consumer Psychology, 8, 377-406. doi:10.1207/s15327663jcp0804_02, http://dx.doi.org/10.1207/s15327663jcp0804_02

Semprini, A. (1999). La marque, les métiers de la sémiotique. Eds de la Fontanille and G.Barrier 147, 156, PULIM, Limoges.

Sheth, J.N., and Parvatiyar A. (1995). Relationship marketing in consumer markets, antecedents and consequences. Journal of the Academy of Marketing Sciences, 23(4), 255-271. doi:10.1177/009207039502300405, http://dx.doi.org/10.1177/009207039502300405

Sirgy, J. (1982). Self-concept in consumer behavior: A critical review. Journal of Consumer Research, 9(3), 287-300. doi:10.1086/208924, http://dx.doi.org/10.1086/208924

Sirieix, L., and Dubois, P.L. (1999). Vers un modèle qualité-satisfaction intégrant la confiance ? Recherches et applications en marketing, 14(3).

Sohier G. (2004). L'influence de la couleur et de la forme du packaging du produit sur la perception de la personnalité de la marque, Actes du XXème Congrès de l'Association Française de Marketing, St Malo. 
Strazzieri A. (1994). Mesurer l'impact durable vis-à-vis d'un produit indépendamment du risque perçu, Recherche et application en marketing, 9(1), 73-91.

Szymaroski D. et BUSH P. (1987). Identifying the Generics-Prone Consumer: A Meta-Analysis. Journal of Marketing Research, vol. 24 (November), 425-431.

Temessek A., and Touzani M. (2004). Une approche intégrative pour l'étude des antécédents de la fidélité à la marque, Actes du Colloque de l'Association Tunisienne de Marketing.

Thomson M., McInnis D.J., and Park C.W. (2005). The Thies that bind: measuring the strength of consumer's emotional attachments to brands. Journal of Consumer Psychology, 15(1), 77-91.

Traylor J. (1981). Product involvement and brand commitment. Journal of Advertising Research, 21, 51-56. doi:10.1207/s15327663jcp1501_10, http://dx.doi.org/10.1207/s15327663jcp1501_10

Tsang, M. M., Ho, S. C., \& Liang, T. P. (2004). Consumer attitudes toward mobile advertising: An empirical study. International Journal of Electronic Commerce, 8(3), 65-78.

Turchetti, D. (2003). March 7. SMS craze unlocks way to youth hearts but tread carefully. Media Asia, 16.

Vargo, S., and R. Lusch. (2004). Evolving to a new dominant logic in Marketing. Journal of Marketing, 68, 1-17. doi:10.1509/jmkg.68.1.1.24036, http://dx.doi.org/10.1509/jmkg.68.1.1.24036

Walsh, M.F. (2005). Consumer Response to Logo Shape Redesign: The Influence of Brand Commitment. [Online]

http://etd.library.pitt.edu/ETD/available/etd-11212005135926/unrestricted/mfwalsh_dissertation.pdf Available:

Yoon, S. (2002). The antecedents and consequences of trust in online purchase decisions. Journal of Interactive Marketing, 16(2) pp.47-63. doi:10.1002/dir.10008, http://dx.doi.org/10.1002/dir.10008

Yuan, S. T., \& Cheng, C. (2004). Ontology-based personalized couple clustering for heterogeneous product recommendation in mobile marketing. Expert Systems with Applications, 26 (4), 461-476. doi:10.1016/j.eswa.2003.10.006, http://dx.doi.org/10.1016/j.eswa.2003.10.006

Zainuddin, N., Russell-Bennett, R., and Hartel, Charmine E.J. (2007). Why Are Businesses Brand Loyal? A Functional Approach to Three Dimensions of B2B Brand Loyalty. In Proceedings 2007 Australia And New Zealand Marketing Academy Conference (ANZMAC), 1872-1879, Dunedin, New Zealand.

Zeithaml, V., Berry, L., and Parasuraman, A. (1996). The behavioural consequences of service quality. Journal of Marketing, 60, 31. doi:10.2307/1251929, http://dx.doi.org/10.2307/1251929

\section{Abbreviations:}

SMS: Shorts Message Service

Ad: advertising

Table 1. Respondents Profile

\begin{tabular}{|l|c|c|}
\hline \multirow{2}{*}{ Gender } & & Percentage \\
\hline \multirow{4}{*}{ Age } & Female & 63.8 \\
\cline { 2 - 3 } & Male & 36.2 \\
\hline \multirow{4}{*}{ Monthly income } & $\geq 20$ & 9 \\
\cline { 2 - 3 } & $20-35$ & 82.8 \\
\cline { 2 - 3 } & 35\& above & 8.2 \\
\cline { 2 - 3 } & Less than 200 DT & 37.5 \\
\cline { 2 - 3 } & 200 DT - 500 DT & 27.6 \\
\cline { 2 - 3 } & 500 DT -1000 DT & 18.9 \\
\cline { 2 - 3 } & 1000 DT - 1500 DT & 9.9 \\
\cline { 2 - 3 } Total & More than 1500 DT & 6.2 \\
\hline
\end{tabular}


Table 2. Description of scales of measurement

\begin{tabular}{|c|c|}
\hline Data & Scale of measurement \\
\hline Brand personality & Aaker $(1997): 42$ items \\
\hline Brand sensitivity & Kapferer et Laurent $(1992): 5$ items \\
\hline Brand involvement & Strazzieri $(1994): 6$ items \\
\hline Brand trust & Gurvez et Korchia $(2002): 8$ items \\
\hline Brand attachment & Lacœuilhe $(2000): 5$ items \\
\hline Brand commitment & Cristau $(2001): 6$ items \\
\hline Purchase intention & Dussart $(1983): 6$ items \\
\hline
\end{tabular}

Table 3. Summary of the Factor Analyses with Varimax Rotation

\begin{tabular}{|c|c|c|c|c|c|c|c|}
\hline & \multicolumn{2}{|c|}{ Brand's personality } & \multirow[t]{2}{*}{ Trust } & \multirow[t]{2}{*}{ Attachment } & \multirow[t]{2}{*}{ Commitment } & \multirow{2}{*}{$\begin{array}{c}\text { Brand } \\
\text { sensitivity }\end{array}$} & \multirow[t]{2}{*}{ Involvemen } \\
\hline & Sincerity & Competence & & & & & \\
\hline KMO & \multicolumn{2}{|c|}{0.794} & 0.833 & 0.784 & 0.777 & 0.794 & 0.875 \\
\hline Variance & $46.192 \%$ & $27.842 \%$ & $55.918 \%$ & $66.040 \%$ & $56.435 \%$ & $63.483 \%$ & $56.912 \%$ \\
\hline
\end{tabular}

Table 4. Summary of the regression Analyses: Brand personality / trust

\begin{tabular}{|l|c|c|c|}
\hline \multicolumn{4}{|c|}{ Brand personality (Sincerity and competence) / trust } \\
\hline & $\boldsymbol{\beta}$ & t-value & Significance \\
\hline Sincerity & 0.21 & 9.632 & 0.000 \\
\hline Competence & 0.3884 & 8.881 & 0.000 \\
\hline
\end{tabular}

Table 5. Summary of the regression Analyses: Brand personality / brand attachment

\begin{tabular}{|c|c|c|c|}
\hline \multicolumn{4}{|c|}{ Brand personality (Sincerity and competence) / brand attachment } \\
\hline \multicolumn{2}{|c|}{$\boldsymbol{\beta}$} & t-value & Significance \\
\hline Sincerity & 0.197 & 4.164 & 0.000 \\
\hline Competence & 0.102 & 2.191 & 0.029 \\
\hline \multicolumn{4}{|c|}{ Brand trust / brand attachment } \\
\hline \multicolumn{2}{|c|}{$\beta$} & t-value & Significance \\
\hline Trust & 0.464 & 9.033 & 0.000 \\
\hline
\end{tabular}

Table 6. Summary of the regression Analyses: brand sensitivity / brand personality / trust

\begin{tabular}{|c|c|c|c|}
\hline \multicolumn{4}{|c|}{ Effect of Brand sensitivity / brand personality / trust } \\
\hline & & t-value & Significance \\
\hline Sensitivity & 0.439 & 9.185 & 0.000 \\
\hline \multicolumn{4}{|c|}{ Effect of Brand involvement / brand personality / trust } \\
\hline & & t-value & Significance \\
\hline Involvemen & 0.284 & 5.552 & 0.000 \\
\hline
\end{tabular}




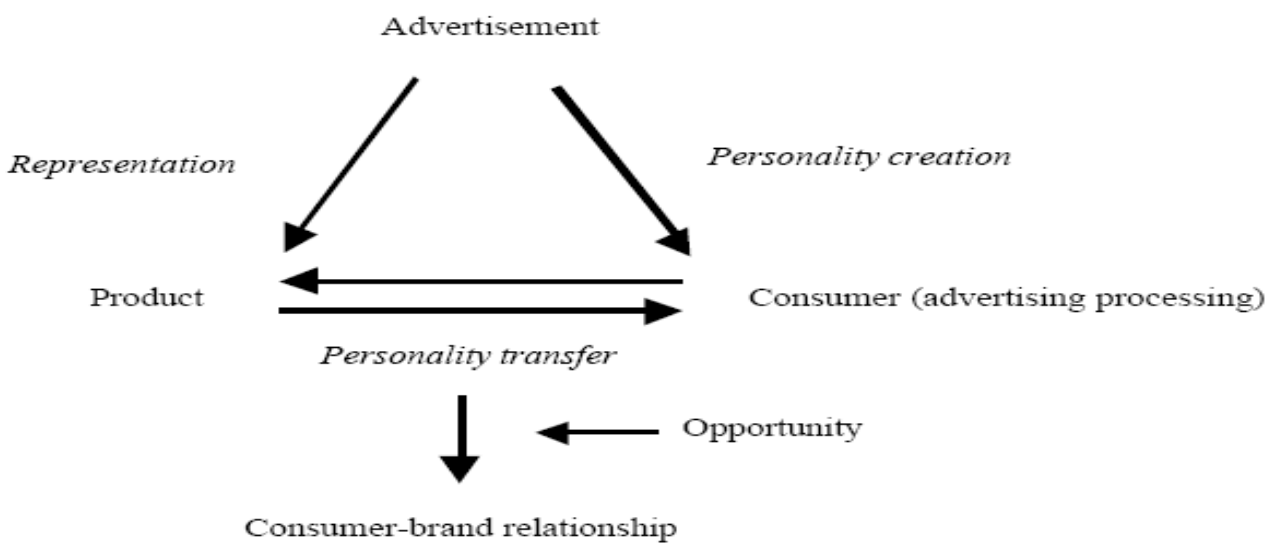

Figure 1. Brand personality creation and transfer

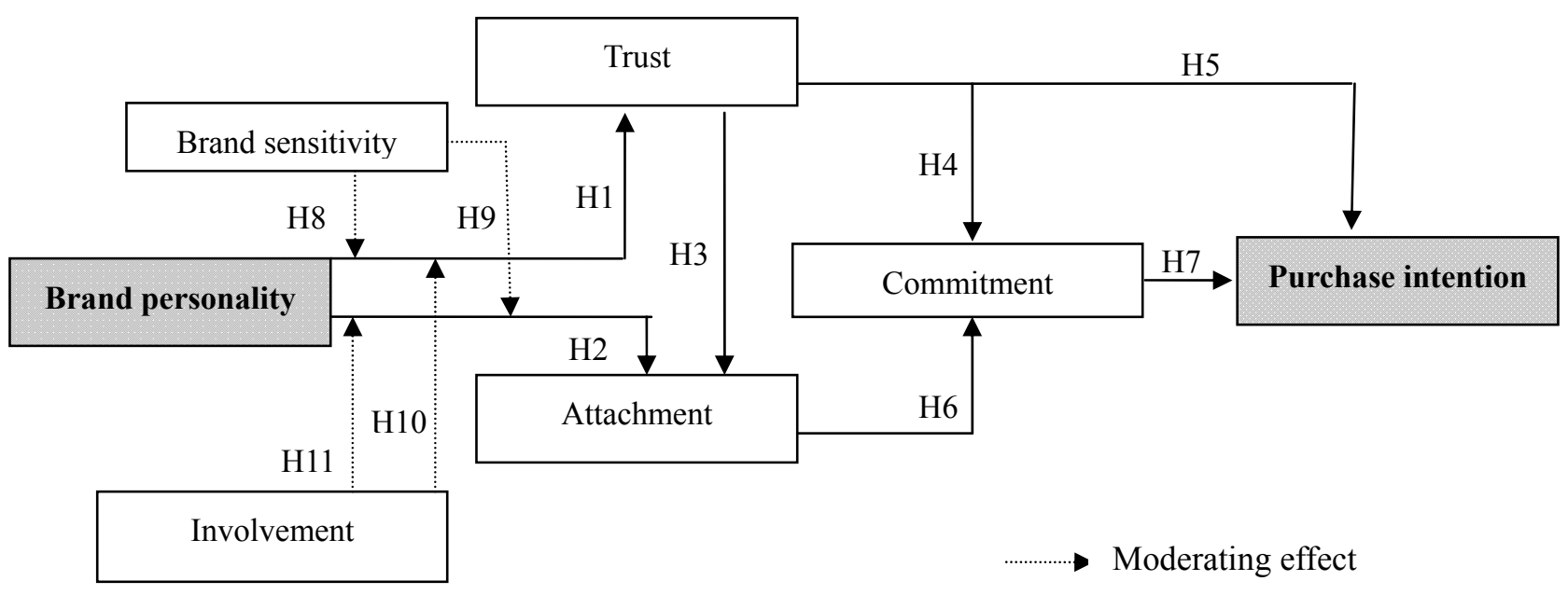

Figure 2. Conceptual framework 